\title{
Dose-dependent onset and cessation of action of inhaled budesonide on exhaled nitric oxide and symptoms in mild asthma
}

\author{
S A Kharitonov, L E Donnelly, P Montuschi, M Corradi, J V Collins, P J Barnes
}

Thorax 2002;57:889-896

See end of article for authors' affiliations

Correspondence to:

Professor P J Barnes,

Department of Thoracic

Medicine, National Heart

and Lung Institute,

Dovehouse Street, London

SW3 6LY;

p.j.barnes@ic.ac.uk

Revised version received 29 April 2002

Accepted for publication 13 May 2002
Background: Dose dependent anti-inflammatory effects of inhaled corticosteroids in asthma are difficult to demonstrate in clinical practice. The anti-inflammatory effect of low dose inhaled budesonide on non-invasive exhaled markers of inflammation and oxidative stress were assessed in patients with mild asthma.

Methods: 28 patients entered a double blind, placebo controlled, parallel group study and were randomly given either 100 or $400 \mu g$ budesonide or placebo once daily, inhaled from a dry powder inhaler (Turbohaler), for 3 weeks followed by 1 week without treatment. Exhaled nitric oxide (NO), exhaled carbon monoxide (CO), nitrite/nitrate, S-nitrosothiols, and 8-isoprostanes in exhaled breath condensate were measured four times during weeks 1 and 4 , and once a week during weeks 2 and 3 . Results: A dose-dependent speed of onset and cessation of action of budesonide was seen on exhaled $\mathrm{NO}$ and asthma symptoms. Treatment with $400 \mu \mathrm{g} /$ day reduced exhaled NO faster $(-2.06$ (0.37) $\mathrm{ppb} /$ day) than $100 \mu \mathrm{g} /$ day $(-0.51$ (0.35) ppb/day; $\mathrm{p}<0.01)$. The mean difference between the effect of 100 and $400 \mu \mathrm{g}$ budesonide was $-1.55 \mathrm{ppb} /$ day $(95 \% \mathrm{Cl}-2.50$ to -0.60$)$. Pretreatment $\mathrm{NO}$ levels were positively related to the subsequent speed of reduction during the first 3-5 days of treatment. Faster recovery of exhaled NO was seen after stopping treatment with budesonide $400 \mathrm{\mu g} /$ day (1.89 (1.43) ppb/day) than $100 \mu \mathrm{g} /$ day $(0.49$ (0.34) ppb/day, $\mathrm{p}<0.01)$. The mean difference between the effect of 100 and $400 \mu \mathrm{g}$ budesonide was $1.40 \mathrm{ppb} /$ day $(95 \% \mathrm{Cl}-0.49$ to 2.31$)$. Symptom improvement was dose-dependent, although symptoms returned faster in patients treated with $400 \mathrm{\mu g} /$ day. A significant reduction in exhaled nitrite/nitrate and S-nitrosothiols after budesonide treatment was not dose-dependent. There were no significant changes in exhaled CO or 8-isoprostanes in breath condensate.

Conclusion: Measurement of exhaled NO levels can indicate a dose-dependent onset and cessation of anti-inflammatory action of inhaled corticosteroids in patients with mild asthma.
$\mathrm{T}$ he optimal anti-inflammatory treatment of mild asthma is uncertain because it is based on indirect measurements of airway inflammation such as symptoms and lung function. Symptoms may not accurately reflect the extent of underlying inflammation due to differences in perception, and lung function may have little room for improvement. Neither of these is able to distinguish the effect of different doses of steroids and both may be affected by bronchodilators. The latter is particularly important because of a recent trend towards use of lower doses of inhaled corticosteroids in combination with long acting $\beta_{2}$ agonists.

There has been an explosion of research into exhaled breath analysis in lung disease. ${ }^{1}$ Exhaled nitric oxide (NO), a marker of airway inflammation, is increased in asthma ${ }^{2}$ and is extremely sensitive to steroid treatment. A significant reduction in exhaled NO has been reported after 6 hours following a single high dose of nebulised budesonide in symptomatic moderate asthma, ${ }^{3}$ or within 2-3 days after high dose inhaled corticosteroids. ${ }^{4}$ A gradual reduction in exhaled NO is seen during the first week of regular treatment ${ }^{4}$ with maximal effect between 3 and 4 weeks. ${ }^{4-6}$ The reduction in exhaled NO has been shown to be dose-dependent when low doses of inhaled corticosteroids are used in patients with mild or moderate asthma. ${ }^{6}$ Such a feature may of use as a non-invasive standardised method of asthma monitoring. ${ }^{78}$

Endogenously produced carbon monoxide $(\mathrm{CO})$, a marker of inflammation and oxidative stress, ${ }^{9}$ is moderately increased in adult ${ }^{10}$ and paediatric asthma. ${ }^{11}$ High levels of nitrite/nitrate $\left(\mathrm{NO}_{2}^{-} / \mathrm{NO}_{3}^{-}\right)$and S-nitrosothiols, products of $\mathrm{NO}$ interaction with superoxide and thiols, have been found in exhaled breath condensate of asthmatic patients. ${ }^{12}$ Recently, increased levels of 8-isoprostane $\mathrm{F}_{2 \alpha^{\prime}}$ a non-invasive marker of oxidative stress, have also been detected in exhaled breath condensate in asthma. $^{13}$

The aim of the present study was to assess the time course of exhaled NO, the primary outcome parameter, during the initiation and cessation of treatment with low doses of inhaled budesonide in well controlled patients with mild asthma. We also compared the effect of steroids on exhaled NO with other non-invasive markers of inflammation and oxidative stress in exhaled breath condensate with lung function and clinical symptoms.

\section{METHODS \\ Patients}

Twenty eight patients ( 16 men) of mean age 28 years (range 25-30) with mild atopic asthma and normal lung function (forced expiratory volume in 1 second $\left(\mathrm{FEV}_{1}\right) 92 \%$ predicted (95\% CI 88 to 96)) took part in the study. All had raised levels of exhaled NO (>11 parts per billion $(\mathrm{ppb}))$, documented reversible airway obstruction which was stable for at least 2 weeks before randomisation, increased bronchial hyperreactivity to methacholine defined as the concentration provoking a fall in $\mathrm{FEV}_{1}$ of $20 \%$ or more $\left(\mathrm{PC}_{20}\right)$ of $<8 \mathrm{mg} / \mathrm{ml}$ (geometric mean $0.42(0.09))$, and positive skin prick tests for at least two common allergens (cat dander, house dust mite, grass pollen, Aspergillus fumigatus). None of the patients was on regular 


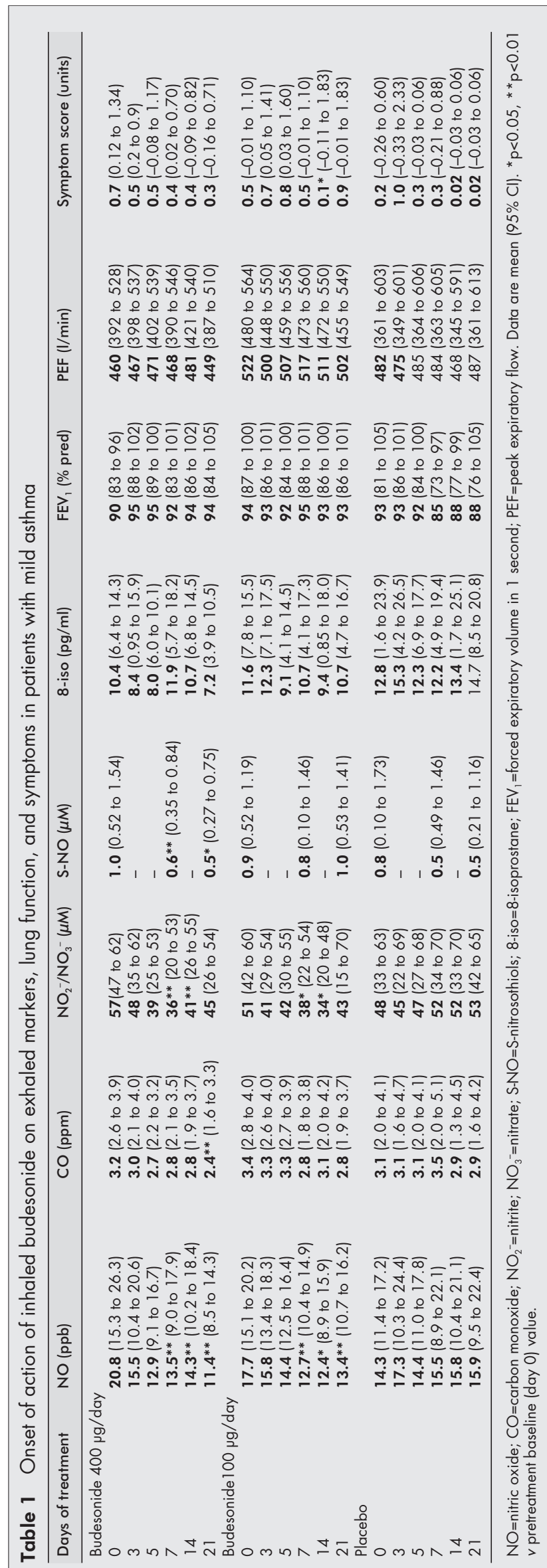

treatment with inhaled or oral corticosteroids, and 21 patients were on inhaled $\beta_{2}$ agonists only. There was no history of upper respiratory tract infection for at least 4 weeks before the study, and none of the studied subjects smoked. Patients did not consume any caffeine for 2 hours or bronchodilators for 6 hours before any assessment.

\section{Study design}

This was a double blind, parallel group, placebo controlled, randomised trial. The study ran for 4 weeks. During visit 1 the subjects were randomised into one of three treatment limbs: group 1 received $400 \mu \mathrm{g}$ budesonide once a day, group 2 received $100 \mu \mathrm{g}$ budesonide once a day, and group 3 received placebo once a day in the morning via a dry powder inhaler (Turbohaler) for 3 weeks. All the groups then completed the study by taking no inhaled steroid for 1 week. The patients attended the clinic on 10 occasions: days 1, 3, 5, and 7 during weeks 1 and 4 and once a week during weeks 2 and 3. All patients were allowed to use terbutaline sulfate via Turbohaler as required during the study. At all visits measurements of exhaled NO, CO, and lung function were made. Exhaled condensate for $\mathrm{NO}_{2}^{-} / \mathrm{NO}_{3}^{-}$measurements was collected on days 1 , 3,5 , and 7 during weeks 1 (onset of action) and 4 (cessation of action), and at the end of the second and third weeks of treatment. Exhaled breath condensate samples for S-nitrosothiols and 8-isoprostane measurements were obtained before the treatment (day 1 ) and at the end of weeks 1 , 2 , and 3 of treatment. Weekly symptom scores were assessed before treatment (diary cards were issued 1 week before the study) and at the end of weeks 1, 2, and 3 of treatment, and finally at the end of the last week of no treatment. In addition, exhaled NO and CO levels were measured before, 3 and 6 hours after the first dose of either $100 \mu \mathrm{g}$ or $400 \mu \mathrm{g}$ budesonide or placebo.

The protocol was approved by the Royal Brompton Hospital ethics committee and written consent was obtained from each patient.

\section{Outcome measures}

\section{Exhaled $\mathrm{NO}$ and $\mathrm{CO}$}

The primary outcome was magnitude and direction of maximal changes of exhaled NO, as a marker of airway inflammation, during the onset and cessation of antiinflammatory action of inhaled steroids, defined as speed of either positive or negative changes in exhaled NO over time. Exhaled NO was chosen because it is not influenced by bronchodilators or by the patients' perception of their symptoms and because of the simplicity of its measurements.

Exhaled NO and CO levels were measured simultaneously by LR2000 analyser (Logan Research Ltd, Rochester, Kent, UK) during a slow exhalation against a resistance and according to the ERS guidelines. ${ }^{7}$ Exhaled CO was measured by an electrochemical sensor with sensitivity from 1 to 500 part per million (ppm) of CO (Logan Research Ltd). The detection limit for $\mathrm{CO}$ was $0.1 \mathrm{ppm}$. The analyser was calibrated weekly with NO certified gas ( $50 \mathrm{ppb} \mathrm{NO}$ in $\mathrm{N}_{2}$, BOC Gases, Guildford, UK) and with CO certified gas ( 500 ppm, Bedfont Scientific LTD, Kent, UK). Ambient $\mathrm{CO}$ was recorded and subtracted from the exhaled CO values. All exhaled NO and CO measurements were carried out before spirometric tests and at least 6 hours after the use of terbutaline.

Nitrite, nitrate, S-nitrosothiols, and 8-isoprostane in exhaled condensate

Breath condensate samples were collected in a specially designed glass condensing chamber that contained a glass double wall and the inner side of the glass was cooled by ice. ${ }^{14}$ Breath condensate was collected between the two glass surfaces, as subjects breathed tidally through a mouthpiece connected to the condenser for 15 minutes while wearing nose 


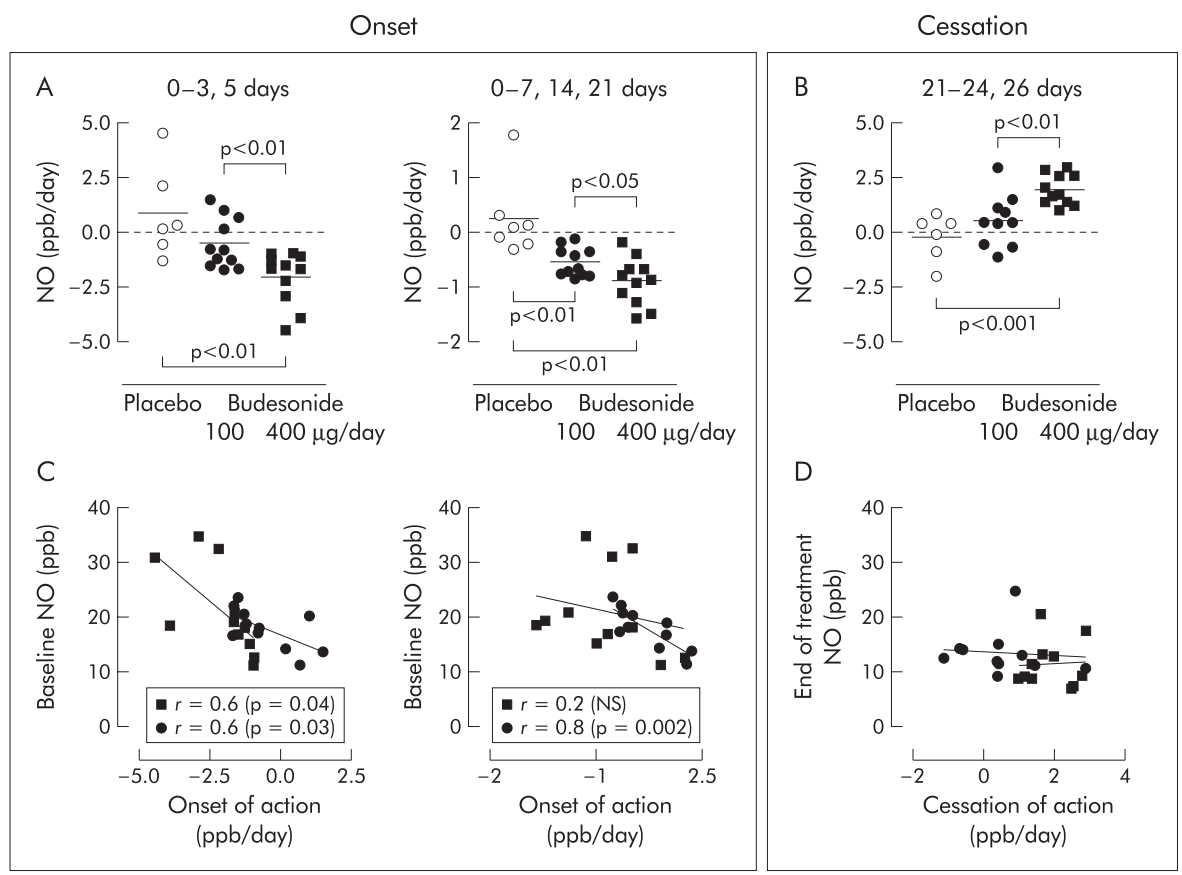

Figure 1 Speed of change in exhaled nitric oxide (NO) during (A) the onset and (B) cessation of action of $100 \mu \mathrm{g} /$ day or $400 \mu \mathrm{g} /$ day budesonide or placebo. (C) Correlation between pretreatment levels of exhaled NO and the subsequent speed of onset of action of budesonide, and (D) between the levels of exhaled NO at the end of the treatment period and the speed of its recovery.

clips. Condensate was stored at $-70^{\circ} \mathrm{C}$ in a $2 \mathrm{ml}$ sterile plastic tube. The levels of both nitrite and nitrate in the condensate were measured according to the method of Misko et al ${ }^{15}$ using a fluorimeter (Labtech, Uckfield, UK), as previously described. ${ }^{16}$ Nitrosothiols were assessed using the Oxonon nitrosothiol detection kit (Alexis Biochemicals, Nottingham, UK), and 8-isoprostane by a specific enzyme immunoassay (EIA) kit (Cayman Chemical, Ann Arbor, USA), as previously described..$^{14}$

\section{Lung function}

$\mathrm{FEV}_{1}$ was measured with a dry spirometer (Vitalograph-S, Vitalograph Ltd, Buckingham, UK). The best value of three manoeuvres was expressed as a percentage of the predicted value. The highest of the three morning and evening peak expiratory flow (PEF) measurements was determined and recorded daily on the diary cards by the patients.

\section{Symptom scores}

Daytime and night time asthma scores were recorded daily by each patient on a 3 point scale as follows. Daytime symptoms: $0=$ none $\quad$ (no symptoms), $1=$ mild (few symptoms, not troublesome), $2=$ moderate (symptoms troublesome), $3=$ severe (not able to carry out normal activities). Night time symptoms: $0=$ none ( slept well throughout the night), $1=$ mild (slept well, woken early or once by asthma), $2=$ moderate (woken 2 or 3 times by asthma), $3=$ severe (bad night, kept awake most of night). In addition, the patients recorded on their diary cards the daily use of inhaled terbutaline.

\section{Statistical analyses}

The primary objective of the study was to assess the onset and duration of anti-inflammatory action of budesonide ( $100 \mu \mathrm{g}$ or $400 \mu$ g once daily) $v$ placebo. The primary variable for this comparison was therefore the speed of changes in exhaled NO, a marker of airway inflammation. There were several secondary variables including lung function parameters, markers in exhaled breath condensate, and asthma symptoms.

To compare the speed of onset and duration of action of three different treatments, we have assessed the magnitude and the direction of maximal negative or positive changes between day 1 and days 3 or 5 in exhaled NO and CO, $\mathrm{NO}_{2}^{-} / \mathrm{NO}_{3}^{-}$in exhaled breath condensate, and $\mathrm{FEV}_{1}$ and $\mathrm{PEF}$ during the first week of treatment and during the last week of the study when treatment was stopped (changes between day 21 and days 24 or 26 ). For example, with maximal exhaled NO reduction of $8 \mathrm{ppb}$ (from $18 \mathrm{ppb}$ at day 1 to $10 \mathrm{ppb}$ at day 5), the calculated speed of $\mathrm{NO}$ changes was $-1.6 \mathrm{ppb} /$ day $(-8 \mathrm{ppb}$ divided by 5 days). If exhaled NO increased from $10 \mathrm{ppb}$ (day 21 ) to $18 \mathrm{ppb}$ (day 26 ), the calculated speed was $+1.6 \mathrm{ppb} /$ day $(+8$ ppb divided by 5 days $)$.

It allowed us to look not only at the direction of fast changes in inflammatory markers, symptoms and lung function, but also to express the data individually in terms of speed as a summary measure, and therefore to compare speed of onset or cessation of action of three different treatments by direct statistical comparison (two tailed unpaired $t$ test). Slower more "chronic" changes of inflammatory markers in exhaled air, condensate, lung function, and symptoms were assessed in a similar fashion by comparing their maximal negative or positive changes after 7, 14, and 21 days of treatment with the levels before treatment.

The comparison between treatment groups to determine whether the maximum effect is similar and happens at the same time, or whether the effect is different, dose-dependent, and happens at different time points, was made by two tailed unpaired $t$ test for the two groups. Matthews ${ }^{17}$ has described a similar approach to the analysis of serial measurements in medical research.

Because of the variability of exhaled NO measurements in the study patients $(\mathrm{n}=28$, mean (SD) 18.2 (6.1) ppb (95\% CI 15.8 to 20.5$)$ ), we calculated that the sample size of 11 would have $70 \%$ power to detect a difference in mean values of 35\% (6.36 ppb). Similar calculations were made for exhaled $\mathrm{NO}_{2}^{-} / \mathrm{NO}_{3}^{-}$(mean (SD) 52.86 (14.18) $\mu \mathrm{M}$ (95\% CI 47.36 to 58.36 ) measurements ( $80 \%$ power to detect a difference in means of $35 \%(18.5 \mu \mathrm{M})$ ); exhaled 8-isoprostane (mean (SD) 13.01 (4.47) pg/ml (95\% CI 11.28 to 14.75 ) measurements $(60 \%$ power to detect a difference in means of $35 \%$ $(4.55 \mathrm{pg} / \mathrm{ml})$ ); exhaled CO (mean (SD) 2.89 (0.79) ppm (95\% 


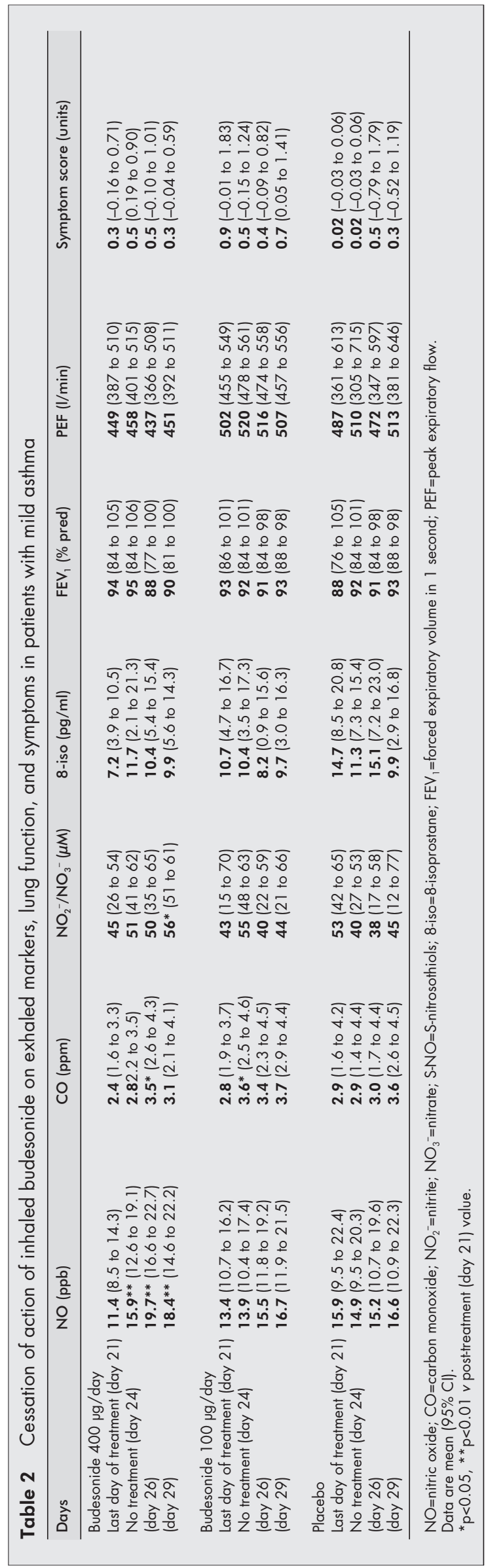

CI 2.58 to 3.19 ) measurements ( $80 \%$ power to detect a difference in means of $35 \%(1.01 \mathrm{ppm}))$; exhaled S-nitrosothiols (mean (SD) 0.84 (0.59) $\mu \mathrm{M}$ (95\% CI 0.61 to 1.06) measurements $(60 \%$ power to detect a difference in means of $35 \%$ $(0.29 \mu \mathrm{M}))$.

The difference was measured by an unpaired $t$ test with a 0.05 two sided significance level. The strength of association between the pretreatment and the speed of subsequent changes of exhaled NO was analysed by Pearson correlation coefficient as the data were normally distributed. Repeated measures procedure was used to analyse the differences between the baseline levels and the levels at any time point during the study within the same group and using the same parameter. A p value of $<0.05$ was considered significant.

\section{RESULTS}

\section{Exhaled gases}

\section{Nitric oxide and carbon monoxide}

Baseline exhaled NO values were similar in all groups (table 1). The onset of action of inhaled budesonide on exhaled NO was dose-dependent, both within the initial phase (first 3-5 days of treatment) and during treatment weeks 1,2, and 3 ( fig 1A). The reduction in exhaled NO during the first 3-5 days was thus significantly faster in the group receiving $400 \mu \mathrm{g} /$ day budesonide $(-2.06(0.37) \mathrm{ppb} /$ day $)$ than in the group receiving $100 \mu \mathrm{g} /$ day $(-0.51(0.35) \mathrm{ppb} /$ day; $\mathrm{p}<0.01)$ or in the placebo group ( -0.89 (0.87) ppb/day). The mean difference between the effect of 100 and $400 \mu \mathrm{g}$ budesonide was $-1.55 \mathrm{ppb} /$ day $(95 \%$ CI -2.50 to -0.60$)$. The speed of the reduction in exhaled NO during the following 3 weeks of treatment was also dosedependent, but slower. There was a significant difference between the effect of $400 \mu \mathrm{g} /$ day $(-0.90(0.13) \mathrm{ppb} /$ day $)$ and $100 \mu \mathrm{g} /$ day $(-0.54(0.08) \mathrm{ppb} /$ day; $\mathrm{p}<0.05)$. The mean difference between the effect of 100 and $400 \mu \mathrm{g}$ budesonide was $-0.36 \mathrm{ppb} /$ day $(95 \% \mathrm{CI}-0.55$ to -0.18 ). The effect of both doses was also different from placebo $(0.26(0.32) \mathrm{ppb} /$ day; $\mathrm{p}<0.01$ and $\mathrm{p}<0.01$, respectively).

Recovery of exhaled NO levels back to pretreatment levels after treatment was stopped was faster in patients treated with $400 \mu \mathrm{g} /$ day budesonide (1.89 (1.43) ppb/day) than $100 \mu \mathrm{g} /$ day (0.49 (0.34) ppb/day, $\mathrm{p}<0.01$; fig $1 \mathrm{~B})$. The mean difference between the effect of 100 and $400 \mu \mathrm{g}$ budesonide was $1.40 \mathrm{ppb} /$ day $(95 \% \mathrm{CI}-0.49$ to 2.31 ). Full recovery of the exhaled NO levels in both groups of patients treated with budesonide was completed by the end of the first week of no treatment (table 2).

There was a weak but significant positive correlation between the pretreatment levels of exhaled NO and the speed of subsequent NO changes during the initial phase (first 3-5 days) of treatment with both doses of budesonide (fig lA). This correlation became stronger in patients treated with the higher dose of budesonide during weeks 1, 2, and 3 of treatment, but was lost in the group treated with $100 \mu \mathrm{g}$ budesonide. No correlation was seen between the "achieved" exhaled NO levels (at the end of week 3 of treatment) and the speed of the subsequent NO recovery during the last week of the study with no treatment (fig lD).

There was no effect of either treatment or placebo on exhaled levels of CO, either during the onset or cessation of their action (tables 1 and 2). No changes compared with baseline were seen in either exhaled NO or CO levels 3 hours (23.0 (3.8) $\mathrm{ppb}$ and $3.0(0.26) \mathrm{ppm}$, respectively, $\mathrm{p}=\mathrm{NS}$ ) or 6 hours (22.9 (3.33) ppb and 2.7 (0.35) ppm, respectively, p=NS) after the first dose of $400 \mu \mathrm{g}$ budesonide; $100 \mu \mathrm{g}$ budesonide also had no effect: NO (18.3 (1.48) ppb at 3 hours and 18.2 (1.69) ppb at 6 hours, $\mathrm{p}=\mathrm{NS})$; $\mathrm{CO}(3.0(0.43) \mathrm{ppm}$ at 3 hours and $3.4(0.22) \mathrm{ppm}$ at 6 hours, $\mathrm{p}=\mathrm{NS})$. Placebo also had no effect (data not shown). 


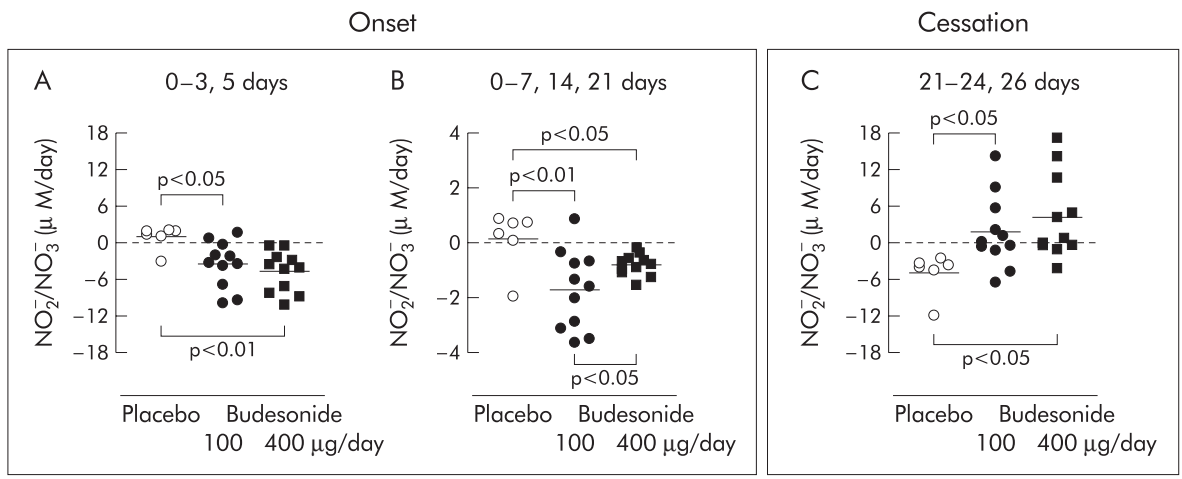

Figure 2 Speed of change in nitrite/nitrate in exhaled breath condensate during (A, B) the onset and (C) the cessation of action of budesonide $100 \mu \mathrm{g} /$ day or $400 \mu \mathrm{g} /$ day or placebo.

\section{Exhaled breath condensate $\mathrm{NO}_{2}^{-} / \mathrm{NO}_{3}^{-}$}

There was rapid reduction in $\mathrm{NO}_{2}^{-} / \mathrm{NO}_{3}^{-}$in exhaled breath condensate (within 3-5 days) following treatment with budesonide at $400 \mu \mathrm{g} /$ day $(-4.82 \quad(0.99) \mu \mathrm{M} /$ day; $\mathrm{p}<0.01)$ and $100 \mu \mathrm{g} /$ day $(-3.55$ (1.14) $\mu \mathrm{M} /$ day) compared with placebo $(0.95(0.80) \mu \mathrm{M} /$ day, $\mathrm{p}<0.05$; fig $2 \mathrm{~A})$. These changes, however, were not dose-dependent. There was a further reduction in $\mathrm{NO}_{2}^{-} / \mathrm{NO}_{3}^{-}$during weeks 1,2 , and 3 of treatment. The lower dose of budesonide caused a faster reduction in $\mathrm{NO}_{2}^{-} / \mathrm{NO}_{3}^{-}$levels $(-1.73(0.44) \mu \mathrm{M} /$ day $)$ than the higher $400 \mu \mathrm{g} /$ day dose $(-0.82(0.12) \mu \mathrm{M} /$ day, $\mathrm{p}<0.05$; fig $2 \mathrm{~B})$. The mean difference between the effect of 100 and $400 \mu \mathrm{g}$ budesonide was $0.91 \mu \mathrm{M}$ /day (95\% CI 0.11 to 1.71 ).

Recovery of $\mathrm{NO}_{2}^{-} / \mathrm{NO}_{3}^{-}$levels in exhaled breath condensate was significantly faster in both the group given budesonide $400 \mu \mathrm{g} /$ day $(4.03(2.07) \mu \mathrm{M} /$ day, $\mathrm{p}<0.05)$ and those treated with $100 \mu \mathrm{g} /$ day ( $1.70(1.79) \mu \mathrm{M} /$ day, $\mathrm{p}<0.05)$ compared with placebo $(-4.93(1.39) \mu \mathrm{M} /$ day $)$. A complete recovery of $\mathrm{NO}_{2}^{-} / \mathrm{NO}_{3}^{-}$levels was achieved by the end of the first week of no treatment (table 2).

\section{Exhaled 8-isoprostane}

No changes in exhaled 8-isoprostanes were seen at any period of the study in either of the groups (tables 1 and 2).

\section{S-nitrosothiols}

Significantly faster reduction in S-nitrosothiols in exhaled breath condensate was seen in patients treated with $400 \mu \mathrm{g} /$ day budesonide $(-0.67(0.20) \mu \mathrm{M} /$ day $)$ than in those treated with $100 \mu \mathrm{g} /$ day $(0.08(0.24) \mu \mathrm{M} / \mathrm{day}, \mathrm{p}<0.05)$. The mean difference between the effect of 100 and $400 \mu \mathrm{g}$ budesonide was $-0.83 \mu \mathrm{M} /$ day $(95 \% \mathrm{CI}-1.66$ to 0.01 ). However, the effect of budesonide was not different from placebo $(-0.23$ (0.44) $\mu \mathrm{M}$ /day). A significant reduction in exhaled S-nitrosothiols compared with pretreatment levels was only seen at the end of treatment weeks 1 and 3 with the higher dose of budesonide (table 1 ).

\section{Lung function and symptom score}

Lung function ( $\mathrm{FEV}$, and PEF) did not change significantly in any of the patient groups (tables 1 and 2, fig 3A). Although most of the patients had mild and occasional asthma

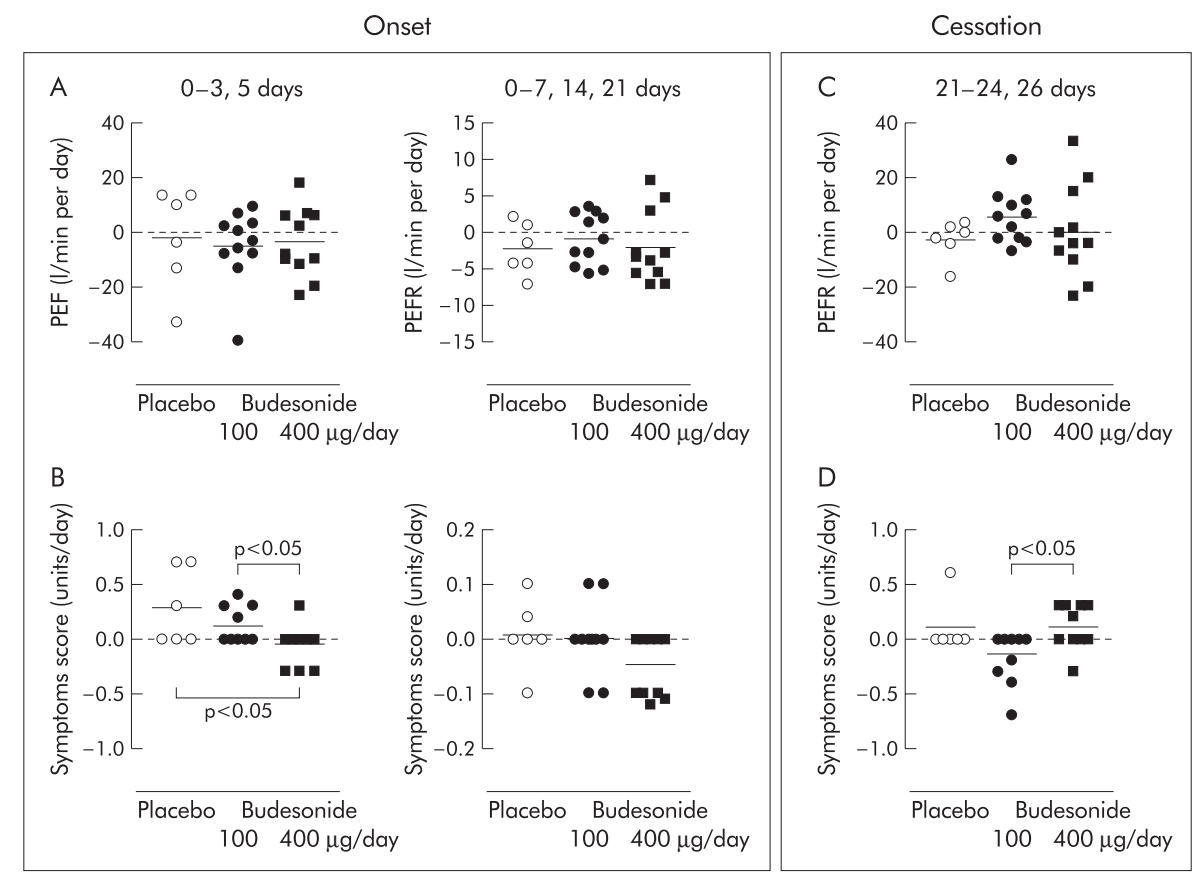

Figure 3 Speed of change in peak expiratory flow (PEF) during the onset (A) and cessation (C) of action of $100 \mu \mathrm{g} /$ day budesonide, $400 \mathrm{\mu g} /$ day budesonide, and placebo. Speed of change in symptom score during the onset (B) and cessation (D) of action of $100 \mu \mathrm{g} / \mathrm{day}$ or $400 \mu \mathrm{g} /$ day budesonide or placebo. 
symptoms (table 1), a significant dose-dependent difference was seen in the speed of reduction of symptom scores between the groups: $400 \mu \mathrm{g} /$ day budesonide $(-0.1 \quad(0.05)$ units/day); $100 \mu \mathrm{g} /$ day budesonide $(0.11$ (0.05) units/day, $\mathrm{p}<0.05)$. The mean difference between the effect of 100 and $400 \mu \mathrm{g}$ budesonide was -0.16 units/day ( $95 \%$ CI -0.36 to 0.03 ). The effect of the higher dose of budesonide was also significantly different from placebo $(0.28(0.14)$ units/day, $\mathrm{p}<0.05)$. All of the symptomatic patients became symptom free between weeks 1 and 3 of treatment with $400 \mu \mathrm{g} /$ day, although two patients treated with the lower dose of budesonide and two in the placebo group became slightly more symptomatic towards the end of the treatment period (fig 3B).

Patients treated with the lower dose of budesonide had a further reduction in their asthma symptoms after treatment was stopped $(-0.15(0.07)$ units/day). In contrast, patients treated with $400 \mu \mathrm{g} /$ day became more symptomatic shortly (within 3-5 days) after treatment was stopped $(0.10$ (0.06) units/day, $p<0.05)$, although by the end of the last week of the study most of the patients in all groups had fewer symptoms than before the study (table 2). The mean difference between the effect of 100 and $400 \mu \mathrm{g}$ budesonide was -0.15 units/day ( $95 \%$ CI -0.30 to 0.01 ).

\section{DISCUSSION}

This is the first study to show the dose-dependent onset and cessation of anti-inflammatory action of inhaled corticosteroids on exhaled $\mathrm{NO}$ and asthma symptoms in patients with mild asthma. We have also shown that higher pretreatment levels of exhaled NO were related to the faster onset of action of budesonide. The speed of recovery of exhaled NO levels and return of asthma symptoms after treatment was stopped was similar to the speed of onset of the anti-inflammatory action of steroids. There were no changes in exhaled levels of $\mathrm{NO}$ and $\mathrm{CO} 3$ and 6 hours after a single dose of either 100 or $400 \mu \mathrm{g}$ budesonide. Rapid reduction and recovery of nitrite/nitrate in exhaled breath condensate during the onset and cessation of action of budesonide was not dosedependent, and a significant reduction in S-nitrosothiols in the exhaled breath condensate was seen only in patients treated with the higher dose of budesonide. There were no changes in exhaled $\mathrm{CO}$ levels, lung function, or 8-isoprostane levels in exhaled breath condensate during the study.

\section{Exhaled NO}

It is difficult to show a dose-dependent effect of inhaled corticosteroids in clinical studies. A large number of patients $(n=473)$ may be required, as well as a long treatment period (12 weeks) with a wide range of doses (200 v $400 v 800 v$ $1600 \mu \mathrm{g} /$ day budesonide) to demonstrate a statistically significant dose-response effect on lung function $\left(\mathrm{FEV}_{1}\right.$ and $\left.\mathrm{PEF}\right){ }^{18}$ If more direct measurements of airway inflammation are used such as changes in bronchial reactivity after allergen challenge, the number of patients required may be smaller $(n=26)$ and the treatment period with similar doses of steroids may be shorter ( 3 weeks), but the dose-related effect will only be seen between the steroids and placebo and not between the doses. ${ }^{19}$ If bronchial reactivity and sputum eosinophilia following an allergen challenge are used as outcome measurements, the dose-dependent effect of low and high doses ( $100 \vee 200 \vee 800 \mu \mathrm{g} /$ day) of mometasone furoate can be seen in a smaller group of patients $(n=12)$ treated for a shorter time ( 6 days).$^{20}$

The problem is that neither of the above approaches resembles the clinical situation. Furthermore, these approaches could not easily be used either in hospital or primary care to adjust and to monitor treatment with corticosteroids.

We have shown that the acute (within first 3-5 days of treatment) and chronic (7-21 days) reduction in exhaled NO is dose-dependent in patients with mild asthma treated with low doses of budesonide. Serial exhaled NO measurements, as we recently suggested, ${ }^{1}$ may therefore be of use to study the onset and duration of action of inhaled corticosteroids and patient compliance. It is still unclear whether exhaled NO levels can be used to study the effect of higher doses of inhaled corticosteroids. We did not find any further reduction in NO levels in patients with mild asthma treated with $1600 \mu \mathrm{g} /$ day budesonide for 3 weeks, although in a separate study a dosedependent reduction in NO levels was found in patients treated with 100 and $400 \mu \mathrm{g} /$ day budesonide for 3 weeks. ${ }^{6}$

The onset of action of steroids on exhaled NO may depend not only on the dose, but also on asthma severity and the route of administration. For example, oral prednisolone ( $30 \mathrm{mg} /$ day) reduced exhaled NO levels by $22 \%$ within 72 hours in mild asthmatics, ${ }^{21}$ but higher doses (180-500 mg) caused a 36\% reduction within 50 hours in patients with acute severe asthma. ${ }^{22}$ All of our patients were mild asthmatics, randomly selected for treatment, and none of the baseline parameters differed significantly between the groups. Differences in the reduction in exhaled NO and faster symptomatic improvement between the groups can therefore be attributed to the dose-dependent effect of the treatment rather than to differences in asthma severity.

Exhaled NO levels may be reduced very rapidly-for example, within 6 hours after a single high dose $(8 \mathrm{mg})$ of nebulised budesonide in patients with moderate symptomatic asthma. ${ }^{3}$ However, we did not find any changes in either exhaled NO or CO levels 3 and 6 hours after a single dose of 100 or $400 \mu \mathrm{g}$ budesonide. It is well established that exhaled NO will be gradually reduced during the first week of regular treatment with inhaled corticosteroids, ${ }^{4}$ with maximal reduction at 3 or 4 weeks. ${ }^{4-6}$

There are several possible explanations for the "fast" and "slow" reduction of exhaled NO levels by corticosteroids. For example, steroids may directly inhibit inducible NO synthase (iNOS). ${ }^{23}$ However, this does not appear to work in primary human airway epithelial cells. ${ }^{24}$ Indirect inhibition may be achieved by suppression of nuclear factor $-\kappa B(N F-\kappa B)^{25}$ by inhibiting the release of proinflammatory cytokines such as tumour necrosis factor $\alpha$ (TNF- $\alpha)$ and interleukin (IL)-1 $\beta$ ) which activate iNOS. ${ }^{26}$ These mechanisms are fast. For example, NF- $\kappa \mathrm{B}$ suppression may be seen within 30 minutes, $^{27}$ leading to downregulation of iNOS activity and reduction of NO in exhaled air. Local interactions between NO and superoxide anions are also important factors as oxidative stress may be responsible for steroid resistance in severe asthma. We have shown that inhaled steroids reduce NO levels in exhaled breath and this is correlated with a reduction in nitrotyrosine, a stable product formed from the interaction between NO and superoxide anions, in bronchial biopsy specimens from patients with mild asthma. ${ }^{28}$

We have speculated that, by knowing the pretreatment exhaled NO levels and the dose of steroids, the speed of their effect may be estimated. Indeed, we have found a weak but significant correlation between the levels of exhaled NO before treatment and the subsequent speed of action of corticosteroids (fig 1B).

An important question is how fast exhaled NO levels take to recover when steroid treatment is stopped. Budesonide has a relatively low glucocorticoid receptor affinity and the half life of active steroid receptor complexes is 5 hours. ${ }^{29}$ Exhaled NO levels in our study recovered rapidly during the first 3-5 days in all patients treated with budesonide, and the full recovery was completed by the end of the week off treatment. Interestingly, the faster recovery of exhaled NO levels in patients treated with $400 \mu \mathrm{g} /$ day budesonide (fig $1 \mathrm{~B}$ ) was independent of the degree of the reduction in exhaled NO by the end of week 3 of treatment (fig lD). The assumption that the effect of $400 \mu \mathrm{g} /$ day budesonide would last longer if treatment was stopped does not therefore appear to be true.

We have previously suggested that exhaled NO levels can be used as a marker for loss of control of asthma ${ }^{30}$ because an 
increase in NO levels and asthma symptoms may be seen before a deterioration in airway hyperresponsiveness and lung function $^{31}$ or an increase in sputum eosinophils ${ }^{32}$ during an exacerbation of asthma. It has recently been shown that exhaled NO levels above $13 \mathrm{ppb}$ have a sensitivity of 0.67 and a specificity of 0.65 to predict a step up in treatment. ${ }^{33}$ Interestingly, our patients treated with $100 \mu$ g/day budesonide were slightly more symptomatic by the end of week 3 of treatment and had higher levels of exhaled NO (13.4 ppb) than during the previous week of treatment (table 1 ). This may suggest that a step up in treatment would have been beneficial, but long term studies are needed using exhaled NO levels to direct treatment.

There is evidence that symptom driven dosing with combination inhalers (inhaled steroid and long acting $\beta_{2}$ agonists) may be used in the future when the dose of the steroid could be determined by the degree of symptoms at a particular time. We suggest that the high sensitivity of exhaled NO may be used to adjust doses based on control of inflammation in asthma treatment. This is important as the long acting $\beta_{2}$ agonist may control symptoms and therefore mask the underlying inflammation which may not be adequately suppressed by corticosteroids. Portable, simple, and inexpensive exhaled NO analysers (based on measurements other than the chemiluminescence principle of NO detection) could be available in the next few years, making this approach feasible in the future.

\section{Exhaled CO}

There were no significant changes in exhaled CO levels in any patients during the study except a reduction after 3 weeks of $400 \mu \mathrm{g} /$ day budesonide which may be a reflection of a modest improvement in oxidative stress in asthma. It is likely that CO might be used as a practical marker to detect and to monitor exacerbations of asthma, ${ }^{30}{ }^{34}$ but its use as a marker of airway inflammation in patients with mild asthma appears to be limited. ${ }^{35}$

\section{Exhaled nitrite/nitrate and S-nitrosothiols}

The reduction in nitrite/nitrate levels in exhaled condensate during the onset and cessation of action of corticosteroids was also fast but was not dose-dependent. This may be a reflection of a rather complex process of nitrite/nitrate formation and metabolism, and the greater variability in the measurements compared with exhaled NO.

NO synthase activity is the major source of $\mathrm{NO}$ which reacts with superoxide anions $\left(\mathrm{O}_{2}^{-}\right)$to form peroxynitrite $\left(\mathrm{ONOO}^{-}\right)^{36}$ and consequently 3 -nitrotyrosine, which is present in asthmatic airways ${ }^{28}$ and is increased in exhaled breath condensate in patients with mild asthma. ${ }^{37}$ We have shown that there is a relationship between exhaled NO levels, iNOS activity, and 3-nitrotyrosine in epithelial cells of asthmatic patients and their reduction after treatment with inhaled corticosteroids. ${ }^{28}$ 3-nitrotyrosine levels in exhaled breath condensate were further increased after steroid withdrawal and subsequent exacerbation in patients with moderate/severe asthma. ${ }^{38}$

Despite the attractive notion that NO synthase activity and $\mathrm{ONOO}^{-}$formation may be the major sources of nitrite/nitrate in exhaled breath condensate, other mechanisms may also contribute. Thus, NO may be formed independently of enzymes from nitrite under acidic conditions, ${ }^{39}$ or it may be generated by peroxidases such as eosinophil peroxidase $(\mathrm{EPO})^{40}$ and myeloperoxidase (MPO) in the presence of nitrite and hydrogen peroxide. ${ }^{41}$ This association, which is found in asthma and other inflammatory disorders, is of importance because peroxidases such as MPO and EPO can efficiently nitrate proteins through mechanisms independent of $\mathrm{ONOO}^{-42}$ EPO can use nitrite as a substrate to nitrate protein tyrosyl residues ${ }^{40}$ or to be an even more potent catalyst of 3-nitrotyrosine formation than $\mathrm{MPO},{ }^{40}$ raising the possibility that EPO may be responsible for 3-nitrotyrosine formation in asthma.
High levels of nitrite have been found in exhaled breath condensate $^{43}$ and sputum ${ }^{44}$ of asthmatic patients, especially during acute exacerbations. ${ }^{43}$ Patients treated with low doses of budesonide had slightly higher exhaled NO levels by the end of the treatment period, which may be explained by a greater variability in the levels of nitrite/nitrate in exhaled breath condensate.

NO can react with sulfhydryl groups to yield S-nitrosothiols ${ }^{45}$ which play an intermediate role in cell metabolism or serve as a carrier for NO. A significant reduction in exhaled S-nitrosothiols compared with pretreatment levels was only seen at the end of weeks 1 and 3 of treatment with high dose budesonide. The speed of recovery of the $\mathrm{S}$-nitrosothiols was similar to the changes in exhaled NO and nitrite/nitrate, suggesting that attenuation of NO production by steroids is the predominant mechanism for the changes in S-nitrosothiols.

\section{Exhaled 8-isoprostane}

$\mathrm{F}_{2}$-isoprostanes are increased in plasma ${ }^{46}$ and bronchoalveolar lavage (BAL) fluid of asthmatic patients, ${ }^{47}$ and levels of 8 -isoprostane are approximately doubled in patients with mild asthma compared with normal subjects, and increased about threefold in those with severe asthma, irrespective of treatment with corticosteroids. ${ }^{13}$ This makes 8-isoprostane a useful marker of asthma severity, in contrast to exhaled NO, in stable well controlled asthmatics treated with steroids. The lack of effect of corticosteroids on exhaled 8-isoprostane in this study provides evidence that inhaled corticosteroids may not be very effective in reducing oxidative stress. Alternatively, the lack of effect of corticosteroids on inhibiting oxidative stress could be a function of their dose.

\section{Symptoms and lung function}

The advantage of exhaled NO measurements is that the changes in NO levels during steroid treatment tend to precede the improvement in symptoms, $\mathrm{FEV}_{1}{ }^{31}$ and sputum eosinophilia. ${ }^{32}$ We have shown that the speed of improvement in asthma symptoms was also dose-dependent. The higher dose of budesonide reduced NO levels and stopped night time asthma symptoms within 3 days in almost all patients. A simultaneous and modest improvement in $\mathrm{FEV}_{1}$ did not show significant dose dependency.

The fact that patients treated with $100 \mu \mathrm{g} /$ day budesonide were slightly more symptomatic by the end of week 3 of treatment and had exhaled NO levels higher than during the previous week of treatment (table 1) suggests that a step up in treatment may be beneficial for these patients, but more studies are needed using exhaled NO to direct treatment.

The recovery in asthma symptoms and in exhaled NO levels was faster in the group treated with $400 \mu \mathrm{g} /$ day budesonide than in those treated with $100 \mu \mathrm{g} / \mathrm{day}$. For both groups recovery of $\mathrm{NO}$ and asthma symptoms preceded the return of $\mathrm{FEV}_{1}$ to the pretreatment level, giving further support to the possibility that exhaled NO may serve as a fast responding indicator of patient compliance with treatment.

\section{Conclusions}

We have shown a rapid and dose-dependent onset of the antiinflammatory effect of inhaled budesonide on exhaled NO levels and symptoms in well controlled mild asthmatic patients. These positive effects of budesonide were associated with a reduction in nitrite/nitrate and S-nitrosothiols in exhaled breath condensate. We have also shown that the effects of inhaled budesonide in sustaining its antiinflammatory effect after its discontinuation is of short duration. Measurement of exhaled NO levels, nitrite/nitrate, and $\mathrm{S}$-nitrosothiols in exhaled breath condensate may provide a rational basis for dose finding studies of anti-inflammatory drugs and antioxidants, and are important end points in clinical trials of these drugs in asthma. The changes in exhaled NO 
levels and other markers may have further clinical relevance in assessing compliance and therapeutic response.

Exhaled NO may also be useful in patients using fixed combination inhalers (corticosteroids and long acting $\beta_{2}$ agonist) to ensure that inflammation is controlled, as this may be difficult to assess from symptoms when a long acting bronchodilator is used at the same time as an inhaled corticosteroid.

\section{Authors' affiliations}

S A Kharitonov, L E Donnelly, P Montuschi, M Corradi, J V Collins, P J Barnes, Department of Thoracic Medicine, National Heart and Lung Institute, Imperial College School of Medicine, Royal Brompton \& Harefield NHS Trust, London SW3 6LY, UK

Supported by AstraZeneca (Lund, Sweden).

\section{REFERENCES}

1 Kharitonov SA, Barnes PJ. Exhaled markers of pulmonary disease. Am J Respir Crit Care Med 2001;163:1693-722.

2 Kharitonov SA, Yates DH, Robbins RA, et al. Increased nitric oxide in exhaled air of asthmatic patients. Lancet 1994;343:133-5

3 Kharitonov SA, Barnes PJ, O'Connor BJ. Reduction in exhaled nitric oxide after a single dose of nebulised budesonide in patients with asthma. Am J Respir Crit Care Med 1996:153:A799.

4 Kharitonov SA, Yates DH, Barnes PJ. Inhaled glucocorticoids decrease nitric oxide in exhaled air of asthmatic patients. Am J Respir Crit Care Med 1996; 153:454-7

$5 \operatorname{Lim} S$, Jatakanon A, John $M$, et al. Effect of inhaled budesonide on lung function and airway inflammation. Am J Respir Crit Care Med 1999;159:22-30

6 Jatakanon A, Kharitonov SA, Lim S, et al. Effect of differing doses of inhaled budesonide on markers of airway inflammation in patients with mild asthma. Thorax 1999:54:108-14.

7 Kharitonov SA, Alving K, Barnes PJ. Exhaled and nasal nitric oxide measurements: recommendations. Eur Respir J 1997;10:1683-93.

8 Anonymous. Recommendations for standardized procedures for the online and offline measurement of exhaled lower respiratory nitric oxide and nasal nitric oxide in adults and children. Am J Respir Crit Care Med 1999:160:2104-17.

9 Donnelly LE, Barnes PJ. Expression of heme oxygenase in human airway epithelial cells. Am J Respir Cell Mol Biol 2001;24:295-303.

10 Zayasu K, Sekizawa K, Okinaga S, et al. Increased carbon monoxide in exhaled air of asthmatic patients. Am J Respir Crit Care Med 1997:156:1140-3.

11 Uasuf CG, Jatakanon A, James A, et al. Exhaled carbon monoxide in childhood asthma. J Pediatr 1999; 135:569-74.

12 Corradi M, Montuschi P, Donnelly LE, et al. Increased nitrosothiols in exhaled breath condensate in inflammatory airway diseases. Am J Respir Crit Care Med 2001:163:854-8.

13 Montuschi P, Corradi M, Ciabattoni G, et al. Increased 8-isoprostane, a marker of oxidative stress, in exhaled condensate of asthma patients. Am J Respir Crit Care Med 1999;160:216-20.

14 Montuschi P, Corradi M, Ciabattoni G, et al. Increased 8-isoprostane, a marker of oxidative stress, in exhaled condensate of asthma patients. Am J Respir Crit Care Med 1999;160:216-20.

15 Misko TP, Schilling RJ, Salvemini D, et al. A fluorometric assay for the measurement of nitrite in biological samples. Anal Biochem 1993;214:11-6

16 Balint B, Donnelly LE, Hanazawa T, et al. Increased nitric oxide metabolites in exhaled breath condensate after exposure to tobacco smoke. Thorax 2001;56:456-61.

17 Matthews JN, Altman DG, Campbell M, et al. Analysis of serial measurements in medical research. BM 1990;300:230-5.

18 Busse WW, Chervinsky P, Condemi J, et al. Budesonide delivered by Turbuhaler is effective in a dose-dependent fashion when used in the treatment of adult patients with chronic asthma.J Allergy Clin Immunol 1998;101:457-63.

19 Wilson AM, Lipworth BJ. Dose-response evaluation of the therapeutic index for inhaled budesonide in patients with mild-to-moderate asthma. Am J Med 2000;108:269-75

20 Inman MD, Watson RM, Rerecich T, et al. Dose-dependent effects of inhaled mometasone furoate on airway function and inflammation after allergen inhalation challenge. Am J Respir Crit Care Med $2001 ; 164: 569-74$
21 Yates DH, Kharitonov SA, Robbins RA, et al. Effect of a nitric oxide synthase inhibitor and a glucocorticosteroid on exhaled nitric oxide. Am J Respir Crit Care Med 1995;152:892-6.

22 Massaro AF, Gaston B, Kita D, et al. Expired nitric oxide levels during treatment of acute asthma. Am J Respir Crit Care Med 1995;152:800-3.

23 Guo FH, Comhair SA, Zheng S, et al. Molecular mechanisms of increased nitric oxide (NO) in asthma: evidence for transcriptional and post-translational regulation of $\mathrm{NO}$ synthesis. J Immunol 2000:164:5970-80.

24 Donnelly LE, Barnes PJ. Expression and regulation of inducible nitric oxide synthase from human primary airway epithelial cells. Am J Respir Cell Mol Biol 2002;26:144-51.

25 Matsumura $M$, Kakishita $H$, Suzuki M, et al. Dexamethasone suppresses iNOS gene expression by inhibiting NF-kappaB in vascular smooth muscle cells. Life Sci 2001;69:1067-77.

26 del Pozo V, de Arruda CE, de Andres B, et al. Eosinophils transcribe and translate messenger RNA for inducible nitric oxide synthase. J Immunol 1997;158:859-64.

27 Tomita K, Chikumi H, Tokuyasu H, et al. Functional assay of NF-kappaB translocation into nuclei by laser scanning cytometry: inhibitory effect by dexamethasone or theophylline. Naunyn Schmiedebergs Arch Pharmacol 1999:359:249-55.

28 Saleh D, Ernst P, Lim S, et al. Increased formation of the potent oxidant peroxynitrite in the airways of asthmatic patients is associated with induction of nitric oxide synthase: effect of inhaled glucocorticoid. FASEB 1998;12:929-37.

29 Johnson $\mathbf{M}$. Development of fluticasone propionate and comparison with other inhaled corticosteroids. J Allergy Clin Immunol 1998;101:S434-9.

30 Kharitonov SA. Exhaled nitric oxide and carbon monoxide in asthma. Eur Respir J 1999;9:212-8.

31 Kharitonov SA, Yates DH, Chung KF, et al. Changes in the dose of inhaled steroid affect exhaled nitric oxide levels in asthmatic patients. Eur Respir J 1996;9:196-201.

32 Jatakanon A, Lim S, Barnes PJ. Changes in sputum eosinophils predict loss of asthma control. Am J Respir Crit Care Med 2000;161:64-72.

33 Griese $M$, Koch M, Latzin $P$, et al. Asthma severity, recommended changes of inhaled therapy and exhaled nitric oxide in children: a prospective, blinded trial. Eur J Med Res 2000:5:334-40.

34 Yamara M, Sekizawa K, Ishizuka $M$, et al. Exhaled carbon monoxide levels during treatment of acute asthma. Eur Respir J 1999;13:757-60.

35 Kharitonov SA, Barnes PJ. Clinical aspects of exhaled nitric oxide. Eur Respir J 2000;16:781-92.

36 Folkerts G, Kloek J, Muijsers RB, et al. Reactive nitrogen and oxygen species in airway inflammation. Eur J Pharmacol 2001;429:251-62.

37 Hanazawa T, Kharitonov SA, Barnes PJ. Increased nitrotyrosine in exhaled breath condensate of patients with asthma. Am J Respir Crit Care Med 2000;162:1273-6.

38 Hanazawa T, Kharitonov SA, Oldfield W, et al. Nitrotyrosine and cysteinyl leukotrienes in breath condensates are increased after withdrawal of steroid treatment in patients with asthma. Am J Respir Crit Care Med 2000;161:A919.

39 Zweier JL, Samouilov A, Kuppusamy P. Non-enzymatic nitric oxide synthesis in biological systems. Biochim Biophys Acta 1999;1411:25062.

40 Wu W, Chen Y, Hazen SL. Eosinophil peroxidase nitrates protein tyrosyl residues. Implications for oxidative damage by nitrating intermediates in eosinophilic inflammatory disorders. J Biol Chem 1999;274:25933-44.

41 Sampson JB, Ye Y, Rosen H, et al. Myeloperoxidase and horseradish peroxidase catalyze tyrosine nitration in proteins from nitrite and hydrogen peroxide. Arch Biochem Biophys 1998;356:207-13.

42 Eiserich JP, Hristova $M$, Cross CE, et al. Formation of nitric oxide-derived inflammatory oxidants by myeloperoxidase in neutrophils. Nature 1998:391:393-7.

43 Hunt J, Byrns RE, Ignarro $\mathrm{L}$, et al. Condensed expirate nitrite as a home marker for acute asthma. Lancet 1995;346:1235-6.

44 Gabazza EC, Taguchi O, Tamaki S, et al. Role of nitric oxide in airway remodelling. Clin Sci (Colch) 2000;98:291-4.

45 Arnelle DR, Stamler JS. NO+, NO, and $\mathrm{NO}^{-}$donation by S-nitrosothiols: implications for regulation of physiological functions by S-nitrosylation and acceleration of disulfide formation. Arch Biochem Biophys 1995;318:279-85.

46 Wood LG, Fitzgerald DA, Gibson PG et al. Lipid peroxidation as determined by plasma isoprostanes is related to disease severity in mild asthma. Lipids 2000;35:967-74.

47 Dworski R, Murray JJ, Jacksonroberts L, et al. Allergen-induced synthesis of F(2)-isoprostanes in atopic asthmatics. Evidence for oxidant stress. Am J Respir Crit Care Med 1999;160:1947-51 